\title{
Optimal drug regimens for primary biliary cirrhosis: a systematic review and network meta-analysis
}

\author{
Gui-Qi Zhu ${ }^{1,2, *}$, Sha Huang ${ }^{1,2, *}$, Gui-Qian Huang ${ }^{1,3, *}$, Li-Ren Wang ${ }^{1,2}$, Yi-Qian Lin ${ }^{1,3}$, \\ Yi-Ming Wu ${ }^{1,2}$, Ke-Qing Shi ${ }^{1,4}$, Jiang-Tao Wang ${ }^{1,2}$, Zhi-Rui Zhou ${ }^{5}$, Martin Braddock ${ }^{6}$, \\ Yong-Ping Chen ${ }^{1,4}$, Meng-Tao Zhou ${ }^{7}$ and Ming-Hua Zheng ${ }^{1,4}$ \\ ${ }^{1}$ Department of Infection and Liver Diseases, Liver Research Center, The First Affiliated Hospital of Wenzhou Medical \\ University, Wenzhou, China \\ ${ }^{2}$ School of the First Clinical Medical Sciences, Wenzhou Medical University, Wenzhou, China \\ ${ }^{3}$ Renji School of Wenzhou Medical University, Wenzhou, China \\ ${ }^{4}$ Institute of Hepatology, Wenzhou Medical University, Wenzhou, China \\ ${ }^{5}$ Department of Radiation Oncology, Fudan University Shanghai Cancer Center; Department of Oncology, Shanghai Medical \\ College, Fudan University, Shanghai, China \\ ${ }^{6}$ Global Medicines Development, AstraZeneca R\&D, Loughborough, United Kingdom \\ 7 Department of Hepatobiliary Surgery, The First Affiliated Hospital of Wenzhou Medical University, Wenzhou, China \\ * These authors are Co-first author \\ Correspondence to: Ming-Hua Zheng, email: zhengmh@wmu.edu.cn
}

Meng-Tao Zhou, email: zmt0417@hotmail.com

Keywords: primary biliary cirrhosis, UDCA-based therapy, adverse events, network meta-analysis, indirect comparison Received: April 11,2015 Accepted: May 22, $2015 \quad$ Published: June 19, 2015

This is an open-access article distributed under the terms of the Creative Commons Attribution License, which permits unrestricted use, distribution, and reproduction in any medium, provided the original author and source are credited.

\section{ABSTRACT}

Objective: Most comprehensive treatments for PBC include UDCA, combination of methotrexate (MTX), corticosteroids (COT), colchicine (COC) or bezafibrate (BEF), cyclosporin A (CYP), D-penicillamine (DPM), methotrexate (MTX), or azathioprine (AZP). Since the optimum treatment regimen remains inconclusive, we aimed to compare these therapies in terms of patient mortality or liver transplantation (MOLT) and adverse event (AE).

Methods: We searched PubMed, Embase, Scopus and the Cochrane Library for randomized controlled trials until August 2014. We estimated HRs for MOLT and ORs for AE. The sensitivity analysis based on dose of UDCA was also performed.

Results: The search identified 49 studies involving 12 different treatment regimens and 4182 patients. Although no statistical significance can be found in MOLT, COT plus UDCA was ranked highest for efficacy outcome amongst all the treatment regimes. While for AEs, compared with OBS or UDCA, monotherapy with COC (OR 5.6, $P<0.001$; OR 5.89, $P<0.001$ ), CYP (OR 3.24, $P<0.001$; OR 3.42, $P<0.001$ ), DPM (OR 8.00, $P<0.001$; OR 8.45, $P<0.001$ ) and MTX (OR 5.31, $P<$ $0.001 ;$ OR 5.61, $P<0.001$ ) were associated with statistically significant increased risk of AEs. No significant differences were found for other combination regimes. Effect estimates from indirect comparisons matched closely to estimates derived from pairwise comparisons. Consistently, in the sensitivity analysis, results closely resembled our primary analysis.

Conclusions: COT plus UDCA was the most efficacious among treatment regimens both for MOLT and AEs. 


\section{INTRODUCTION}

Primary biliary cirrhosis (PBC) is a chronic progressive inflammatory autoimmune- mediated liver disease that primarily affects middle-aged women with a gender ratio of 1:10 [1]. The annual incidence of primary biliary cirrhosis ranges from 1 to 49 persons per million, and the prevalence was estimated between 7 to 402 persons per million [2].

So far, some single or combined therapies have been studied by randomized controlled trials (RCTs). However, which treatment regime is optimal for patients with $\mathrm{PBC}$ remains controversial. Although UDCA is the only medical treatment that has received U.S. Food and Drug Administration approval [3], the effects of UDCA evaluated by several clinical studies have yielded conflicting results. Some randomized clinical trials (RCT) have confirmed that UDCA is an effective medical treatment for the disease [4-7]. Also, UDCA has been shown to improve not only symptoms, liver enzymes, and liver histology, but also patient survival [8-9]. Conversely, two comprehensive traditional meta-analyses which include 16 recent RCTs concluded that the use of UDCA did not demonstrate any benefit on mortality and mortality or live transplantation (MOLT) [10-11]. Furthermore, PBC disease continued to progress in many patients who do not show complete response during UDCA therapy, hence, additional medical treatment or other drugs are urgently required.

Other drugs for the treatment of PBC have been studied for the past decade as single agents or adjuvant medications, which are mainly immunomodulatory and other agents, such as colchicine (COC), cyclosporin A (CYP), D-penicillamine (DPM), methotrexate (MTX), corticosteroids (COT), bezafibrate (BEF), or azathioprine (AZP). Although some of these drugs when administered as monotherapy showed little benefit for patients with PBC in clinical outcomes from several conventional meta-analyses, we are still unable to identify the clinical effects of drugs evaluated in traditional meta-analysis with a small number of included studies. Moreover, addition of these treatments to UDCA was evaluated by some studies. Combination therapy with UDCA and COC in patients with $\mathrm{PBC}$ has been evaluated in a small study and in a large double blind, placebo-controlled study [12-13]. Results from the Japanese study (12) indicate no benefits from the addition of COC to UDCA, whilst the French RCT (13) suggests that the addition of COC to UDCA provides only a marginal advantage over UDCA monotherapy. The role of combination therapy with MTX and UDCA were evaluated by Leung et al, which showed a clinical improvement compared with that predicted by the Mayo model $[3,14]$. However, another RCT evaluating a combination of MTX plus UDCA demonstrated that there was no improvement in symptoms and the regime may have been associated with substantial toxicity.
Consistently, the clinical outcomes of other additional therapies (COT or BEF) to UDCA still remain unclear or yield inconsistent results $[2,15]$.

Therefore, in order to attempt to resolve this issue, which theoretically may be answered by conducting a very large clinical trial with multiple comparator arms, of conflicting results in $\mathrm{PBC}$ treatments for patients, we performed the network meta-analysis, which allows us to integrate direct and indirect comparisons to simultaneously compare several treatments [16-18]. The objective of network meta-analysis was to apply the established methodology used in network meta-analysis to an area of clinical practice where no such previous studies have existed. In such cases, our aims were to summarize a much broader evidence base and to indirectly compare the relative efficacy and safety of these treatments with most comprehensive therapies (AZP, MTX, COT, COC, CYP, DPM, UDCA, MTX plus UDCA, COT plus UDCA, COC plus UDCA or BEF plus UDCA) for patients with PBC.

\section{RESULTS}

\section{Study characteristics}

3133 studies were identified for review of title and abstract (Supplementary 1). After the initial screening, we retrieved the full text of potentially eligible articles for detailed assessment, 3084 articles were excluded. We included forty-nine eligible studies for meta-analysis, with a total of 4182 patients who received one of the eleven treatment strategies including monotherapy with UDCA, AZP, MTX, COT, COC, CYP, DPM, combination of MTX plus UDCA, COT plus UDCA, COC plus UDCA, BEF plus UDCA or observation (Figure 1). The duration of treatment ranged from three months to ten years, and the mean age of trial participants was 55.3 years and ranged from 24 to 79 years. Most trials (47 [96\%] of 31) were two-grouped studies and only two [19-20] were threegrouped studies and mean study sample was 41.8 patients per group (minimum-maximum 4-176). For the primary outcome, twelve unique comparisons were available for 40 [2, 4-5, 7, 15, 20-37] different trials. In terms of outcome of safety, there were also $40[2-5,7,12-13,20$ $32,34-35,38-55]$ trials providing data for twelve unique comparisons. Table 1 summarizes the characteristics of the included forty-nine studies. Supplementary 2 shows the quality assessment parameter assessed by the Cochrane Risk of Bias tool, which was rated as good, even though some studies did not reported details regarding randomization and allocation concealment. 
Table 1: Characteristics of included studies

\begin{tabular}{|c|c|c|c|c|c|c|c|c|}
\hline \multirow[t]{2}{*}{$\begin{array}{l}\text { Author } \\
\text { (Year) }\end{array}$} & \multirow[t]{2}{*}{ Country } & \multirow[t]{2}{*}{$\begin{array}{l}\text { Mean age } \\
\text { (range) }\end{array}$} & \multirow[t]{2}{*}{ Treatment/Control } & \multirow[t]{2}{*}{ Dose } & \multirow[t]{2}{*}{$\begin{array}{l}\text { Treatment } \\
\text { duration }\end{array}$} & \multirow[t]{2}{*}{ Study size } & \multirow{2}{*}{$\begin{array}{c}\text { Mortality or liver } \\
\text { transplantation (\%) }\end{array}$} & \multirow{2}{*}{$\begin{array}{l}\text { Adverse events (\%) } \\
\text { Treatment/Control }\end{array}$} \\
\hline & & & & & & & & \\
\hline $\begin{array}{l}\text { Itakura } \\
(2004)\end{array}$ & Japan & $57(47-67)$ & $\begin{array}{c}\text { BEF plus } \\
\text { UDCA/UDCA }\end{array}$ & $\begin{array}{c}\text { BEF: } 400 \mathrm{mg} \text { per day; UDCA: } \\
600 \mathrm{mg} \text { per day }\end{array}$ & 6 months & 16 & $8 / 6$ & $11 / 14$ \\
\hline $\begin{array}{l}\text { Iwasaki (a) } \\
\text { (2008) }\end{array}$ & Japan & $56(45-67)$ & $\begin{array}{c}\text { BEF plus } \\
\text { UDCA/UDCA }\end{array}$ & $\begin{array}{c}\text { BEF: } 400 \mathrm{mg} \text { per day; UDCA: } \\
\quad 600 \mathrm{mg} \text { per day }\end{array}$ & 52 weeks & 22 & $0 / 0$ & $42 / 10$ \\
\hline $\begin{array}{l}\text { Iwasaki (b) } \\
\quad(2008)\end{array}$ & Japan & $56(28-75)$ & $\mathrm{BEF} / \mathrm{UDCA}$ & $\begin{array}{l}\text { BEF : } 400 \mathrm{mg} \text { daily orally } \\
\text { UDCA: } 600 \mathrm{mg} \text { daily }\end{array}$ & 52 weeks & 45 & $\mathrm{NR} / \mathrm{NR}$ & \\
\hline $\begin{array}{l}\text { Kanda } \\
(2003)\end{array}$ & Japan & $57(52-72)$ & $\begin{array}{c}\text { BEF plus } \\
\text { UDCA/UDCA }\end{array}$ & $\begin{array}{c}\text { BEF: } 400 \mathrm{mg} \text { per day; UDCA: } \\
\quad 600 \mathrm{mg} \text { per day }\end{array}$ & 6 months & 22 & $11 / 11$ & $18 / 9$ \\
\hline $\begin{array}{l}\text { Leuschner } \\
\text { (1999) }\end{array}$ & German & $50(40-60)$ & $\begin{array}{c}\text { COT plus } \\
\text { UDCA/UDCA }\end{array}$ & $\begin{array}{l}\text { COT: } 3 \mathrm{mg} \text { three times daily; } \\
\text { UDCA: } 10-15 \mathrm{mg} / \mathrm{kg} / \text { day in } \\
\text { three divided doses }\end{array}$ & 2 years & 40 & $5 / 5$ & $10 / 5$ \\
\hline $\begin{array}{l}\text { Combes } \\
(2005)\end{array}$ & $\begin{array}{l}\text { United } \\
\text { States }\end{array}$ & $53(42-60)$ & $\begin{array}{c}\text { MTX plus } \\
\text { UDCA/UDCA }\end{array}$ & $\begin{array}{l}\text { MTX: in four doses over } 48 \\
\text { hours (total dose } 10 \mathrm{mg} / \text { week); } \\
\text { UDCA: } 500 \mathrm{mg} \text { per day }\end{array}$ & 117 months & 265 & NR/NR & $10 / 9$ \\
\hline $\begin{array}{l}\text { Gonzalez-K } \\
\text { och (1997) }\end{array}$ & Chile & $53(45-75)$ & $\begin{array}{c}\text { MTX plus } \\
\text { UDCA/UDCA }\end{array}$ & $\begin{array}{l}\text { UDCA: } 13-15 \mathrm{mg} / \mathrm{kg} / \text { day } \\
\text { MTX: } 0.25 \mathrm{mg} / \mathrm{kg} / \text { week }\end{array}$ & 48 weeks & 25 & $12 / 10$ & $25 / 8$ \\
\hline $\begin{array}{l}\text { Lindor } \\
(1995)\end{array}$ & $\begin{array}{l}\text { United } \\
\text { States }\end{array}$ & $59.5(40-75)$ & $\begin{array}{c}\text { MTX plus } \\
\text { UDCA/UDCA/OBS }\end{array}$ & $\begin{array}{l}\text { UDCA: } 13-15 \mathrm{mg} / \mathrm{kg} / \text { day } \\
\text { MTX: } 0.25 \mathrm{mg} / \mathrm{kg} / \text { week }\end{array}$ & 2 years & 121 & $\mathrm{NR} / \mathrm{NR} / \mathrm{NR}$ & $22 / \mathrm{NR} / \mathrm{NR}$ \\
\hline $\begin{array}{l}\text { Leung } \\
(2011)\end{array}$ & $\begin{array}{l}\text { United } \\
\text { States }\end{array}$ & $54(52-56)$ & $\begin{array}{c}\text { MTX plus } \\
\text { UDCA/COC plus } \\
\text { UDCA }\end{array}$ & $\begin{array}{c}\text { UDCA: } 13-15 \mathrm{mg} / \mathrm{kg} / \text { day; } \\
\text { MTX:0.25mg/kg/week; COC: } \\
1 \mathrm{mg} / \text { day }\end{array}$ & 10 years & 29 & $\mathrm{NR} / \mathrm{NR}$ & $\mathrm{NR} / \mathrm{NR}$ \\
\hline $\begin{array}{c}\text { Battezzati } \\
\text { (1993) }\end{array}$ & Italy & $57(42-60)$ & UDCA/OBS & $500 \mathrm{mg}$ per day & 1 year & 88 & $43 / 43$ & $9 / 2$ \\
\hline $\begin{array}{l}\text { Combes } \\
(1995)\end{array}$ & $\begin{array}{l}\text { United } \\
\text { States }\end{array}$ & $49(52-56)$ & UDCA/OBS & 10 to $12 \mathrm{mg} / \mathrm{kg} /$ day & 2 years & 151 & $70 / 70$ & $17 / 16$ \\
\hline $\begin{array}{c}\text { Eriksson } \\
\text { (1997) }\end{array}$ & Sweden & $57(46-70)$ & UDCA/OBS & $500 \mathrm{mg}$ per day & 2 years & 116 & $58 / 52$ & $12 / 7$ \\
\hline $\begin{array}{l}\text { Heathcote } \\
\text { (1994) }\end{array}$ & Canada & $56(50-62)$ & UDCA/OBS & $14 \mathrm{mg} / \mathrm{kg} /$ day & 2 years & 222 & $91 / 94$ & $16 / 24$ \\
\hline $\begin{array}{l}\text { Hwang } \\
(1993)\end{array}$ & China & $58(50-66)$ & UDCA/OBS & $600 \mathrm{mg} /$ day. & 3 months & 12 & $6 / 6$ & $17 / 17$ \\
\hline $\begin{array}{c}\text { Leuschner } \\
\text { (1989) }\end{array}$ & German & $53(53-73)$ & UDCA/OBS & $10 \mathrm{mg} / \mathrm{kg} /$ day & 9 months & 20 & $9 / 9$ & $10 / 10$ \\
\hline $\begin{array}{l}\text { Lindor } \\
\text { (1994) }\end{array}$ & $\begin{array}{l}\text { United } \\
\text { States }\end{array}$ & $53(51-55)$ & UDCA/OBS & 13 to $15 \mathrm{mg} / \mathrm{kg} /$ day & 4 years & 180 & $75 / 68$ & $8 / 13$ \\
\hline Oka (1990) & Japan & $59(51-67)$ & UDCA/OBS & $600 \mathrm{mg} /$ day & 24 weeks & 52 & $25 / 25$ & $15 / 4$ \\
\hline $\begin{array}{l}\text { Papatheodo } \\
\text { ridis (2002) }\end{array}$ & Greece & $54(44-64)$ & UDCA/OBS & 12 to $15 \mathrm{mg} / \mathrm{kg} /$ day & 92 months & 86 & $26 / 29$ & $53 / 40$ \\
\hline $\begin{array}{l}\text { Pares } \\
(2000)\end{array}$ & Spain & $54(44-64)$ & UDCA/OBS & 14 to $16 \mathrm{mg} / \mathrm{kg} /$ day & 2 years & 192 & $89 / 89$ & $26 / 18$ \\
\hline $\begin{array}{l}\text { Poupon } \\
(1991)\end{array}$ & France & $56(47-65)$ & UDCA/OBS & 13 to $15 \mathrm{mg} / \mathrm{kg} / \mathrm{day}$ & 2 years & 146 & $67 / 63$ & $15 / 26$ \\
\hline $\begin{array}{l}\text { Turner } \\
\text { (1994) }\end{array}$ & England & $57(54-60)$ & UDCA/OBS & $10 \mathrm{mg} / \mathrm{kg} /$ day & 2 years & 46 & $21 / 21$ & $27 / 29$ \\
\hline $\begin{array}{c}\text { Vuoristo } \\
\text { (1995) }\end{array}$ & Finland & $55(50-60)$ & UDCA/OBS & 12 to $15 \mathrm{mg} / \mathrm{kg} /$ day & 2 years & 59 & $29 / 26$ & $3 / 29$ \\
\hline
\end{tabular}




\begin{tabular}{|c|c|c|c|c|c|c|c|c|}
\hline $\begin{array}{l}\text { Chazouiller } \\
\text { es (1998) }\end{array}$ & France & $50(47-53)$ & $\begin{array}{l}\text { UDCA/COT plus } \\
\text { UDCA }\end{array}$ & $\begin{array}{l}\text { UDCA: } 13 \text { to } 15 \mathrm{mg} / \mathrm{kg} / \mathrm{day} \text {; } \\
\text { COT: } 0.5 \mathrm{mg} / \mathrm{kg} / \text { day }\end{array}$ & 23 months & 11 & $3 / 5$ & $20 / 33$ \\
\hline $\begin{array}{l}\text { Gunsar } \\
(2002)\end{array}$ & Turkey & $44(40-55)$ & $\begin{array}{l}\text { UDCA/COT plus } \\
\text { UDCA }\end{array}$ & $\begin{array}{l}\text { UDCA: } 13 \mathrm{mg} / \mathrm{kg} / \text { day; COT: } \\
0.5 \mathrm{mg} / \mathrm{kg} / \text { day }\end{array}$ & 28 months & 20 & $12 / 5$ & $15 / 14$ \\
\hline $\begin{array}{l}\text { Chazouiller } \\
\text { es (2006) }\end{array}$ & France & $41(39-57)$ & $\begin{array}{l}\text { UDCA/COT plus } \\
\text { UDCA }\end{array}$ & $\begin{array}{l}\text { UDCA: } 13 \text { to } 15 \mathrm{mg} / \mathrm{kg} / \text { day; } \\
\text { COT: } 0.5 \mathrm{mg} / \mathrm{kg} / \text { day }\end{array}$ & 90 months & 17 & NR/NR & NR/NR \\
\hline $\begin{array}{l}\text { Heurgue } \\
(2007)\end{array}$ & France & $44(41-56)$ & $\begin{array}{l}\text { UDCA/COT plus } \\
\text { UDCA }\end{array}$ & $\begin{array}{l}\text { UDCA: } 13 \text { to } 15 \mathrm{mg} / \mathrm{kg} / \text { day; } \\
\text { COT: } 0.5 \mathrm{mg} / \mathrm{kg} / \text { day }\end{array}$ & 60 months & 13 & NR/NR & NR/NR \\
\hline $\begin{array}{l}\text { Ozaslan } \\
(2010)\end{array}$ & Turkey & $44(40-51)$ & $\begin{array}{l}\text { UDCA/COT plus } \\
\text { UDCA }\end{array}$ & $\begin{array}{l}\text { UDCA: } 13 \text { to } 15 \mathrm{mg} / \mathrm{kg} / \text { day; } \\
\text { СОT: } 0.5 \mathrm{mg} / \mathrm{kg} / \text { day }\end{array}$ & 31 months & 12 & $2 / 6$ & NR/NR \\
\hline $\begin{array}{l}\text { Tanaka } \\
(2011)\end{array}$ & Japan & $54(50-60)$ & $\begin{array}{l}\text { UDCA/COT plus } \\
\text { UDCA }\end{array}$ & $\begin{array}{c}\text { UDCA: } 10 \mathrm{mg} / \mathrm{kg} / \text { day; COT: } \\
0.5 \mathrm{mg} / \mathrm{kg} / \text { day }\end{array}$ & 73 months & 25 & $14 / 8$ & NR/NR \\
\hline $\begin{array}{l}\text { Ikeda } \\
(1996)\end{array}$ & Japan & $57(55-60)$ & $\begin{array}{c}\text { COC plus } \\
\text { UDCA/UDCA }\end{array}$ & $\begin{array}{c}\text { COC: } 1 \mathrm{mg} / \mathrm{kg} / \text { day; UDCA: } \\
600 \mathrm{mg} / \text { day }\end{array}$ & 30 months & 22 & NR/NR & $30 / 8$ \\
\hline $\begin{array}{l}\text { Poupon } \\
\text { (1996) }\end{array}$ & France & $53(51-55)$ & $\begin{array}{c}\text { COC plus } \\
\text { UDCA/UDCA }\end{array}$ & $\begin{array}{l}\text { COC: } 1 \mathrm{mg} / \mathrm{d}, 5 \text { days per week; } \\
\text { UDCA: } 13-15 \mathrm{mg} / \text { day }\end{array}$ & 2 years & 74 & NR/NR & $5 / 3$ \\
\hline $\begin{array}{l}\text { Almasio } \\
(2000)\end{array}$ & Italy & $55(45-65)$ & $\begin{array}{c}\text { COC plus } \\
\text { UDCA/UDCA }\end{array}$ & $\begin{array}{c}\text { COC: } 1 \text { mg/daily; UDCA: } 500 \\
\mathrm{mg} / \text { daily }\end{array}$ & 3 years & 90 & $35 / 41$ & $4 / 2$ \\
\hline $\begin{array}{c}\text { Battezzati } \\
(2001)\end{array}$ & Italy & $58(48-68)$ & $\begin{array}{c}\text { COC plus } \\
\text { UDCA/UDCA }\end{array}$ & $\begin{array}{c}\text { COC: } 1 \text { mg/daily; UDCA: } 500 \\
\mathrm{mg} / \text { daily }\end{array}$ & 10 years & 44 & $14 / 8$ & NR/NR \\
\hline $\begin{array}{c}\text { Christensen } \\
\text { (1985) }\end{array}$ & Denmark & $55(25-78)$ & $\mathrm{AZP} / \mathrm{OBS}$ & 300 to $700 \mathrm{mg} /$ week & 11 years & 248 & $58 / 72$ & $6 / 7$ \\
\hline $\begin{array}{c}\text { Heathcote } \\
\text { (1976) }\end{array}$ & UK & $51(24-79)$ & $\mathrm{AZP} / \mathrm{OBS}$ & $2 \mathrm{mg} / \mathrm{kg} /$ day & 5 years & 45 & $36 / 52$ & $16 / 0$ \\
\hline $\begin{array}{l}\text { Lombard } \\
\text { (1993) }\end{array}$ & UK & $54(44-64)$ & $\mathrm{CYP} / \mathrm{OBS}$ & $3 \mathrm{mg} / \mathrm{kg} /$ day & 928 days & 349 & $17 / 18$ & $56 / 42$ \\
\hline $\begin{array}{l}\text { Minuk } \\
(1988)\end{array}$ & Canada & $51(41-61)$ & CYP/OBS & $2.5 \mathrm{mg} / \mathrm{kg} / \mathrm{day}$ & 1year & 12 & $0 / 17$ & $100 / 17$ \\
\hline $\begin{array}{l}\text { Wiesner } \\
(1990)\end{array}$ & USA & $46(37-57)$ & CYP/OBS & $4 \mathrm{mg} / \mathrm{kg} /$ day & 2.7 years & 29 & $5 / 30$ & $79 / 50$ \\
\hline $\begin{array}{c}\text { Dickson } \\
(1985)\end{array}$ & USA & $46(36-56)$ & DPM/OBS & $250 \mathrm{mg} /$ day & 10 years & 227 & $40 / 40$ & $53 / 22$ \\
\hline $\begin{array}{l}\text { Epstein } \\
(1981)\end{array}$ & UK & $53(43-63)$ & DPM/OBS & $\begin{array}{l}\text { over } 8 \text { to } 10 \text { weeks from } 150 \\
\mathrm{mg} / \text { day to } 600 \mathrm{mg} / \text { day }\end{array}$ & 6 years & 98 & $30 / 43$ & $31 / 3$ \\
\hline $\begin{array}{l}\text { Matloff } \\
(1982)\end{array}$ & USA & $52(42-62)$ & DPM/OBS & $1 \mathrm{~g} /$ day & 28 months & 52 & $62 / 12$ & $35 / 4$ \\
\hline $\begin{array}{l}\text { Neuberger } \\
(1985)\end{array}$ & UK & $53(41-62)$ & DPM/OBS & $\begin{array}{c}1.2 \mathrm{~g} / \text { day, increased from } 300 \\
\mathrm{mg} \text { by } 300 \mathrm{mg} \text { each fortnight } \\
\text { until } 1.2 \mathrm{~g}\end{array}$ & 4 years & 189 & $54 / 32$ & $36 / 8$ \\
\hline $\begin{array}{c}\text { Taal } \\
(1983)\end{array}$ & $\begin{array}{c}\text { Netherlan } \\
\text { ds }\end{array}$ & $51(43-62)$ & DPM/OBS & $\begin{array}{l}1 \mathrm{~g} / \text { day (increased from } 250 \\
\text { mg every month until } 1 \mathrm{~g} \text { for } \\
\text { the first } 6 \text { months. After that, } \\
\text { decreased to } 500 \mathrm{mg} / \text { day for } \\
\text { the remaining } 6 \text { months }\end{array}$ & 1 years & 24 & $18 / 31$ & $100 / 85$ \\
\hline $\begin{array}{l}\text { Mitchison } \\
\text { (1992) }\end{array}$ & England & $52(44-60)$ & СOT/OBS & $\begin{array}{l}\text { initially } 30 \mathrm{mg} / \text { day then } \\
\text { reduced by } 5 \mathrm{mg} / \text { day every two } \\
\text { weeks until a maintenance dose } \\
\text { of } 10 \mathrm{mg} / \text { day was reached. }\end{array}$ & 3 years & 36 & $16 / 29$ & $79 / 24$ \\
\hline $\begin{array}{l}\text { Hendrickse } \\
\text { (1999) }\end{array}$ & England & $57(55-59)$ & MTX/OBS & $7.5 \mathrm{mg} /$ week. & 6 years & 60 & $40 / 37$ & $83 / 73$ \\
\hline $\begin{array}{l}\text { Kaplan } \\
(2003)\end{array}$ & USA & $51(50-53)$ & MTX plus COC & $\begin{array}{l}\text { MTX: } 15 \mathrm{mg} / \text { week, } 5 \mathrm{mg} \text { every } \\
12 \text { hours } 3 \text { times. }\end{array}$ & 2 years & 85 & $57 / 44$ & $17 / 7$ \\
\hline
\end{tabular}




\begin{tabular}{|c|c|c|c|c|c|c|c|c|}
\hline & & & & COC: $0.6 \mathrm{mg}$ twice daily & & & & \\
\hline $\begin{array}{l}\text { Kaplan } \\
\text { (1999) }\end{array}$ & USA & $51(50-53)$ & COC plus MTX & $\begin{array}{l}\text { COC: } 0.6 \mathrm{mg} \text { twice daily } \\
\text { MTX: } 15 \mathrm{mg} / \mathrm{wk} \text {, taken as } 5 \\
\text { mg every } 12 \text { hours } 3 \text { times }\end{array}$ & 24 months & 85 & $23 / 29$ & $N R / N R$ \\
\hline $\begin{array}{l}\text { Kaplan } \\
(1986)\end{array}$ & USA & $48(40-68)$ & COC/OBS & $0.6 \mathrm{mg}$ twice daily. & 2 years & 60 & $20 / 47$ & $13 / 3$ \\
\hline $\begin{array}{l}\text { Warnes } \\
(1987)\end{array}$ & UK & $53(47-64)$ & COC/OBS & $1 \mathrm{mg} /$ day & 18 months & 64 & $15 / 30$ & $56 / 7$ \\
\hline $\begin{array}{c}\text { Bodenheim } \\
\text { er(1988) }\end{array}$ & USA & $52(34-59)$ & COC/OBS & $0.6 \mathrm{mg}$ twice daily. & 5 years & 57 & NR/NR & $14 / 3$ \\
\hline $\begin{array}{l}\text { Zifroni } \\
\text { (1991) }\end{array}$ & USA & $57(50-65)$ & $\mathrm{COC} / \mathrm{OBS}$ & $0.6 \mathrm{mg}$ twice daily. & 4 years & 57 & $46 / 48$ & $11 / 0$ \\
\hline
\end{tabular}

\section{Results from pair-wise comparisons}

Seven different comparisons were accomplished in pairwise meta-analysis. The weighted HRs for MOLT and ORs for AEs, respectively, were calculated for each comparison. The geometric distribution of controlled trials on MOLT (Figure 1A) and AEs (Figure 1B) were displayed. The weighted hazard ratios and odds ratios for the two outcomes, MOLT and AEs, were calculated for each comparison. Statistical heterogeneity was assessed using the $\mathrm{I}^{2}$ statistic, which was assessable in two of the comparisons.

Overall, statistical heterogeneity was moderate, although for some comparisons $95 \%$ CIs were wide and included values indicating very high or no heterogeneity (Table 2). In the meta-analyses of direct comparisons for efficacy, $\mathrm{I}^{2}$ values higher than $75 \%$ were recorded for only two comparisons: COC plus UDCA versus UDCA

\section{A. Mortality or liver transplantation}

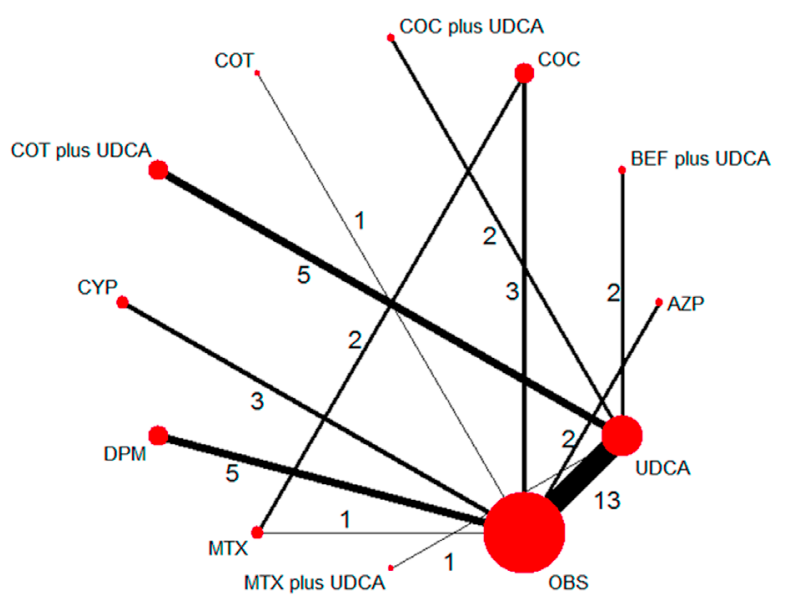

(86.9\%), with two studies in the meta-analysis, and DPM versus OBS, with five studies included. While in terms of AEs, $\mathrm{I}^{2}$ values higher than $50 \%$ were recorded for only one comparison: CYP versus OBS (52.6\%), with three studies in the meta-analysis, and the remaining comparisons were all lower than $40 \%$. In addition, all $P$ values for Begg's rank correlation test and Egger's test were greater than 0.05 , indicating that no publication bias was found amongst those pairwise comparisons of different treatment regimens. (Table 3)

\section{Results from the network meta-analysis of primary and secondary outcomes}

Figure 2A and Figure 2B illustrates the HRs and ORs for MOLT and AEs respectively and $95 \%$ confidence intervals obtained from the indirect comparisons of the included regimens. Following Figure 2A from left to right,

\section{B. Adverse events}

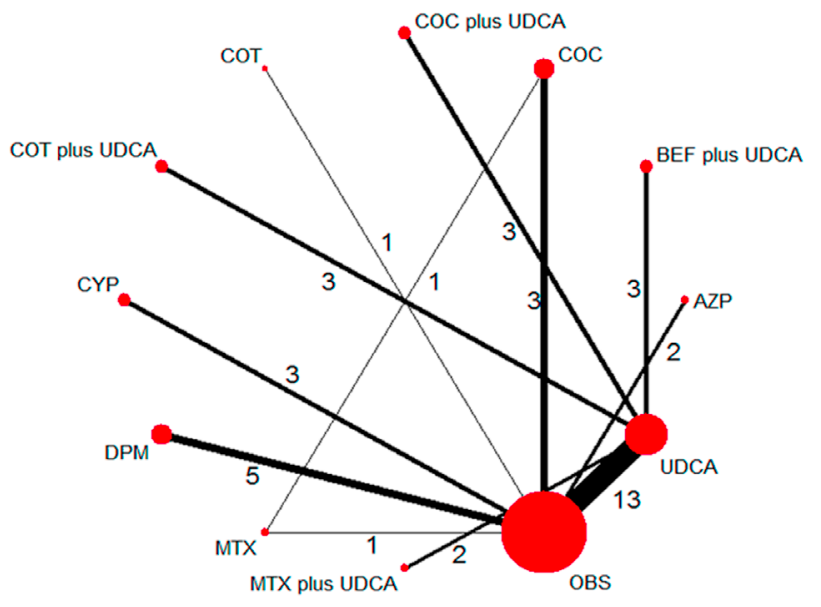

Figure 1: Network of the comparisons for the Bayesian network meta-analysis. The numbers along the link lines indicate the number of trials or pairs of trial arms. Lines connect the interventions that have been studied in head-to-head (direct) comparisons in the eligible controlled trials. The width of the lines represents the cumulative number of trials for each comparison and the size of every node is proportional to the number of enrolled participants (sample size). COC: colchicine; BEF: bezafibrate; COT: corticosteroids; MTX: methotrexate; UDCA: ursodeoxycholic acid; CYP: cyclosporin A; DPM: D-penicillamine; AZP: azathioprine; OBS: observation. A. Mortality or liver transplantation; B. Adverse events 
Table 2: Comparison of outcomes between pair-wise meta-analysis and network meta-analysis

\begin{tabular}{|c|c|c|}
\hline Treatment comparisons & Results of pair-wise meta-analysis & Results of network meta-analysis \\
\hline \multicolumn{3}{|l|}{ Clinical improvement } \\
\hline MTX vs OBS & $1.15(0.41,3.26)$ & $0.95(0.32,2.78)$ \\
\hline DPM vs OBS & $1.51(0.63,3.61)$ & $1.54(0.76,3.17)$ \\
\hline CYP vs OBS & $0.57(0.17,1.88)$ & $0.53(0.16,1.46)$ \\
\hline COT vs OBS & $0.45(0.09,2.26)$ & $0.43(0.05,3.34)$ \\
\hline COC vs OBS & $0.50(0.24,1.01)$ & $0.57(0.25,1.26)$ \\
\hline MTX vs COC & $1.51(0.80,2.88)$ & $1.67(0.64,4.29)$ \\
\hline AZP vs OBS & $0.54(0.33,0.88)$ & $0.53(0.18,1.56)$ \\
\hline UDCA vs OBS & $0.93(0.65,1.31)$ & $0.78(0.45,1.27)$ \\
\hline UDCA vs UDCA plus COT & $0.68(0.20,2.27)$ & $0.38(0.09,1.39)$ \\
\hline UDCA vs UDCA plus BEF & $0.75(0.04,14.58)$ & $0.77(0.06,9.89)$ \\
\hline MTX plus UDCA vs UDCA & $0.42(0.03,5.30)$ & $0.74(0.24,2.44)$ \\
\hline COC plus UDCA vs UDCA & $1.17(0.09,14.55)$ & $1.05(0.33,3.26)$ \\
\hline \multicolumn{3}{|l|}{ Adverse events } \\
\hline MTX VS OBS & $1.82(0.52,6.38)$ & $5.31(1.21,24.83)$ \\
\hline COC vs MTX & $2.67(0.64,11.11)$ & $1.07(0.23,4.65)$ \\
\hline DPM VS OBS & $5.27(3.34,8.30)$ & $8.00(3.50,22.46)$ \\
\hline CYP VS OBS & $3.24(0.90,11.64)$ & $3.24(1.21,13.42)$ \\
\hline COT VS OBS & $12.19(2.53,58.72)$ & $6.08(0.80,47.58)$ \\
\hline COC VS OBS & $8.91(3.11,25.56)$ & $5.60(1.95,18.04)$ \\
\hline AZP VS OBS & $1.78(0.25,12.56)$ & $1.60(0.42,7.30)$ \\
\hline UDCA vs OBS & $0.96(0.64,1.44)$ & $0.95(0.59,1.56)$ \\
\hline UDCA vs COT plus UDCA & $1.08(0.24,4.89)$ & $1.42(0.17,11.86)$ \\
\hline UDCA vs UDCA plus BEF & $2.58(0.58,11.57)$ & $3.16(0.59,20.67)$ \\
\hline UDCA vs UDCA plus MTX & $1.30(0.58,2.94)$ & $1.54(0.50,5.96)$ \\
\hline UDCA vs UDCA plus COC & $2.66(0.65,10.92)$ & $3.12(0.63,18.75)$ \\
\hline
\end{tabular}

Notes: COC: colchicine; BEF: bezafibrate; COT: corticosteroids; MTX: methotrexate; UDCA: ursodeoxycholic acid; OBS: observation; CYP: cyclosporin A; DPM: D-penicillamine; AZP: azathioprine; NA: not available; 
Table 3: Assessment of heterogeneity and publication bias for trials included in the traditional meta-analysis

\begin{tabular}{|c|c|c|c|}
\hline Treatment comparisons & $\mathrm{I}^{2}(\%)$ & $P$ values of Begg's test & P values of Egger's test \\
\hline \multicolumn{4}{|l|}{ Mortality or liver transplantation } \\
\hline MTX vs OBS & NR & NR & NR \\
\hline DPM vs OBS & 79.8 & 0.62 & 0.84 \\
\hline CYP vs OBS & 29.5 & 0.60 & 0.28 \\
\hline COT vs OBS & NR & NR & NR \\
\hline COC vs OBS & 16.5 & 0.60 & 0.44 \\
\hline MTX vs COC & 0.0 & 0.32 & NR \\
\hline AZP vs OBS & 0.0 & 0.32 & NR \\
\hline UDCA vs OBS & 1.0 & 0.89 & 0.53 \\
\hline UDCA vs UDCA plus COT & 0.0 & 0.33 & 0.08 \\
\hline UDCA vs UDCA plus BEF & 0.0 & NA & NA \\
\hline MTX plus UDCA vs UDCA & 0.0 & NA & NA \\
\hline COC plus UDCA vs UDCA & 86.9 & 0.32 & NA \\
\hline \multicolumn{4}{|l|}{ Adverse events } \\
\hline UDCA vs OBS & 35.8 & 0.90 & 0.77 \\
\hline MTX vs OBS & NR & NR & NR \\
\hline DPM vs OBS & 0.0 & 0.62 & 0.13 \\
\hline CYP vs OBS & 52.6 & 0.12 & 0.39 \\
\hline COT vs OBS & NR & NR & NR \\
\hline COC vs OBS & 0.0 & 1.00 & 0.23 \\
\hline MTX vs COC & NR & NR & NR \\
\hline AZP vs OBS & 45.7 & 0.32 & NR \\
\hline UDCA vs COT plus UDCA & 0.0 & 0.12 & 0.06 \\
\hline UDCA vs UDCA plus BEF & 0.0 & 0.12 & 0.12 \\
\hline UDCA vs UDCA plus MTX & 3.3 & 0.32 & NA \\
\hline UDCA vs UDCA plus COC & 0.0 & 0.12 & 0.30 \\
\hline
\end{tabular}

Notes: COC: colchicine; BEF: bezafibrate; COT: corticosteroids; MTX: methotrexate; UDCA: ursodeoxycholic acid; OBS: observation; CYP: cyclosporin A; DPM: D-penicillamine; AZP: azathioprine; NA: not available. 
although differing not significantly, there was a trend that combination of COT plus UDCA was most effective in reducing the risk of MOLT than AZP (HR 3.78, 95\%CI 0.63 to 23.74 ), COC (HR 3.52, 95\%CI 0.71 to 18.96 ), COT (HR 4.77, 95\%CI 0.37 to 66.21), CYP (HR 3.81, $95 \%$ CI 0.66 to 26.50 ), DPM (HR $1.31,95 \% \mathrm{CI} 0.27$ to 6.66), MTX (HR 2.14, 95\%CI 0.36 to 13.09 ), OBS (HR $2.01,95 \%$ CI 0.50 to 8.84 ), monotherapy with UDCA (HR 2.63, 95\%CI 0.72 to 10.75 ), COC plus UDCA (HR 2.55, $95 \%$ CI 0.44 to 15.03 ), MTX plus UDCA (HR 3.58, 95\% CI
0.61 to 21.96 ) or BEF plus UDCA (HR 3.48, 95\%CI 0.21 to 56.93). Consistently, Figure $2 \mathrm{~B}$ shows that for AEs, when compared with OBS, COC (HR 0.18, 95\%CI 0.06 to 0.51 ), CYP (HR $0.31,95 \%$ CI 0.07 to 0.83 ), DPM (HR $0.13,95 \% \mathrm{CI} 0.04$ to 0.29 ) and MTX (HR $0.19,95 \% \mathrm{CI}$ 0.04 to 0.83 ) yielded a significant difference in causing AEs. In addition, compared with UDCA, a statistical significance was also achieved in COC (HR 0.17, 95\% CI 0.05 to 0.55 ), CYP (HR $0.29,95 \%$ CI 0.07 to 0.87 ), DPM (HR 0.12, 95\%CI 0.04 to 0.31 ) and MTX (HR 0.18,

\section{A. Mortality or liver transplantation}

\begin{tabular}{|c|c|c|c|c|c|c|c|c|c|c|c|}
\hline 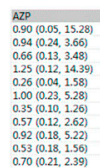 & 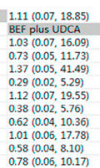 & 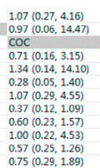 & 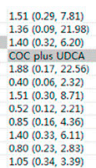 & 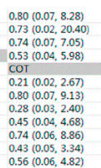 & 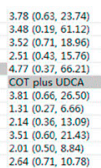 & 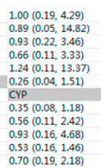 & 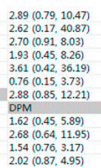 & 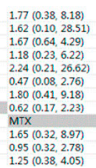 & 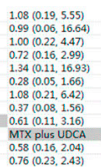 & 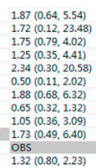 & 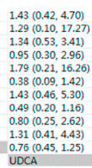 \\
\hline
\end{tabular}

\section{B. Adverse events}

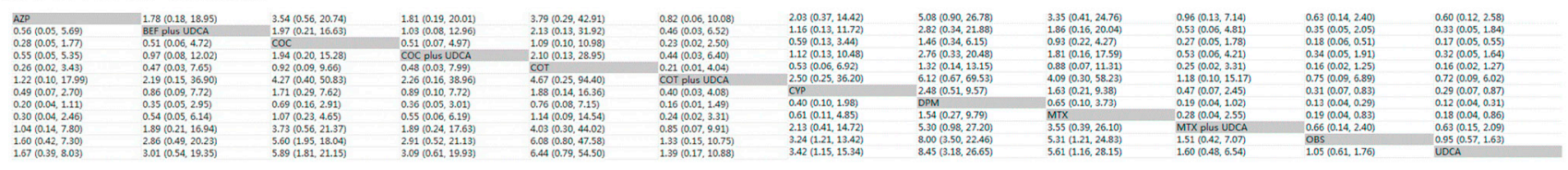

Figure 2: Clinical efficacy and safety of all treatments according to network meta-analysis. Treatments are reported in alphabetical order. The ORs were estimated in upper and lower triangle comparing column-defining with row-defining treatment. A. Mortality or liver transplantation; B. Adverse events. For mortality or liver transplantation, HRs higher than 1 favor the column-defining treatment, while for adverse effects, ORs lower than 1 favor the row-defining treatment. COC: colchicine; BEF: bezafibrate; COT: corticosteroids; MTX: methotrexate; UDCA: ursodeoxycholic acid; CYP: cyclosporin A; DPM: D-penicillamine; AZP: azathioprine; OBS: observation. A. Mortality or liver transplantation; B. Adverse events
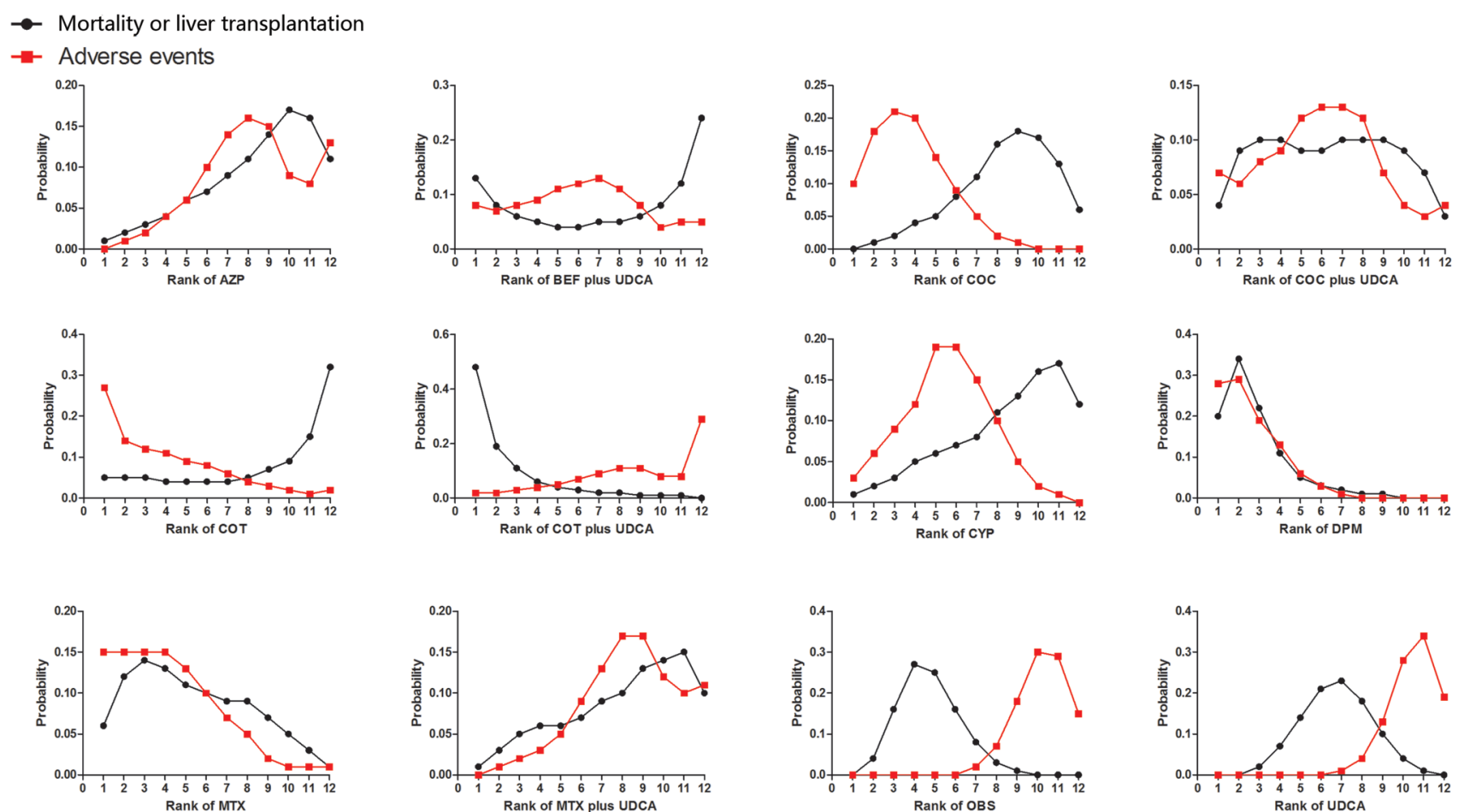

Figure 3: Rankograms showing probability of each strategy having each specific rank (1-6) for mortality or liver transplantation and adverse events. Ranking indicates the probability to be the best treatment, the second best, the third best and so on. Rank 1 is worst and rank $\mathrm{N}$ is best. COC: colchicine; BEF: bezafibrate; COT: corticosteroids; MTX: methotrexate; UDCA: ursodeoxycholic acid; CYP: cyclosporin A; DPM: D-penicillamine; AZP: azathioprine; OBS: observation. 


\section{$95 \%$ CI 0.04 to 0.86 ).}

Figure 3 shows the distribution of probabilities for each treatment being ranked at different positions for the outcome of MOLT or AEs. Although the efficacy effects of combined therapy of COT plus UDCA compared with OBS compared with placebo was not statistically significant, COT plus UDCA had the greatest probability (48\%) for being the best treatment option on reducing risk of MOLT. While in terms of AEs, DPM had the highest probabilities $(28 \%)$ of reduction in AEs (Figure 3 ), suggesting DPM was more likely to cause AEs than remaining treatments. On the other hand, COC or COT plus UDCA demonstrated the least adverse events, the cumulative probabilities of being ranked first and second in with respect to the safety profile was combination of COC or COT and UDCA. Figure 4 presents comparisonadjusted funnel plot for UDCA-based therapies network, without the evidence of asymmetry.

\section{Comparisons between traditional pairwise and network meta-analyses}

Table 2 shows the results of traditional pairwise and network meta-analyses. Although the pooled estimates showed small differences, the confidence intervals from traditional pairwise meta-analyses and the credible intervals from Bayesian network meta-analyses in general overlapped. The P-values show no significant difference between the direct and indirect effects (Table 4). In general, the node splitting method showed no significant inconsistency within the networks for any of the two outcomes.

\section{Sensitivity analysis}

In the sensitivity analysis, there were eleven trials $[2,12,22,24-25,27-28,31,33,35,39]$ excluded which reported patients administrated by high (more than 500 $\mathrm{mg} / \mathrm{kg} /$ day) dose of UDCA (BEF plus UDCA excluded). Thirty-eight independent studies were performed for the primary outcome, MOLT. Overall, the sensitivity analysis showed that omitting those trials with high dose UDCA did not impact on the ranking order and statistical significance of the remaining treatments. Supplementary $3 \mathrm{~A}$ indicates that combination of COT and UDCA was the top-ranked treatments, although differ not significantly. Similar findings were also observed for the outcome of AEs. DPM, COC or CYP were associated with significant effects in causing AEs compared with OBS. Besides, COT or COC plus UDCA were ranked the least possibility to cause AEs (Supplementary 3B).

\section{A. Mortality or liver transplantation}

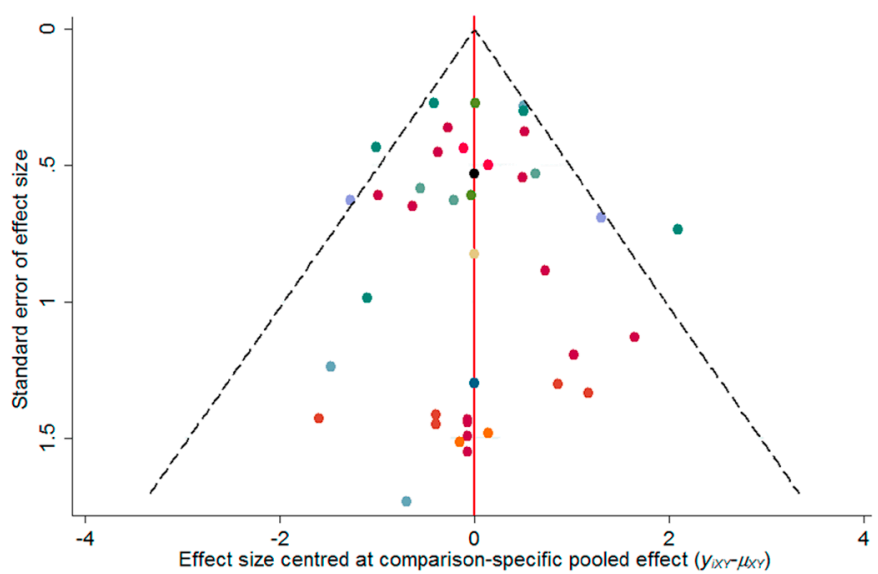

\section{B. Adverse events}

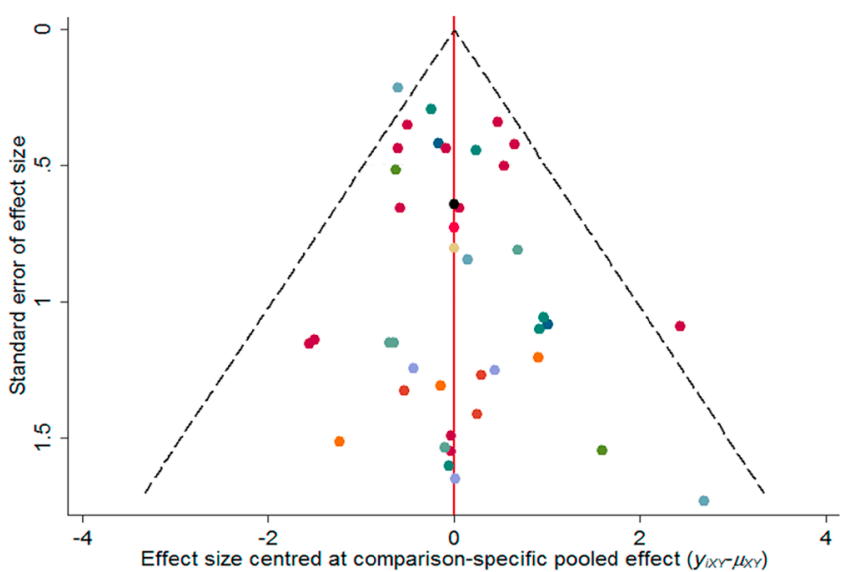

- MTX plus UDCA vs UDCA OBS vs UDCA $\bullet A Z P$ vs OBS• BEF plus UDCA vs UDCA $\bullet$ COC vs OBS - COC plus UDCA vs UDCA COT vs OBS - COT plus UDCA vs UDCA - CYP vs OBS - DPM vs OBS

- COC vs MTX • MTX vs OBS

Figure 4: Comparison-adjusted funnel plot for the treatment network in terms of mortality or liver transplantation and adverse events. The red line represents the null hypothesis that the study-specific effect sizes do not differ from the respective comparison-specific pooled effect estimates. Different colors correspond to different comparisons. Estimates below one indicate that the benefit of the experimental intervention is more pronounced in the trial than the pooled estimate. Observations from small studies missing on the right side of the line of null effect (ratio of rate ratios $>1$ ) indicate that small studies tend to exaggerate the effectiveness of experimental treatments. COC: colchicine; BEF: bezafibrate; COT: corticosteroids; MTX: methotrexate; UDCA: ursodeoxycholic acid; CYP: cyclosporin A; DPM: D-penicillamine; AZP: azathioprine; OBS: observation. A. Mortality or liver transplantation; B. Adverse events 
Mortality or liver transplantation

COC vs MTX

COC vs OBS

COC vs UDCA

MTX vs OBS

COC plus UDCA vs MTX plus UDCA

COC plus UDCA vs UDCA

MTX plus UDCA vs UDCA

Adverse events

COC vs MTX

COC vs OBS

MTX vs OBS
0.76

0.21

0.10

0.73

0.69

0.67

0.69

0.07

0.07

0.07

Notes: COC: colchicine; MTX: methotrexate; UDCA: ursodeoxycholic acid; OBS: observation

\section{DISCUSSION}

In this network meta-analysis reviewing the efficacy and safety of most comprehensive interventions in patients with $\mathrm{PBC}$ to date, we found that combined therapy with COT and UDCA was the most effective in reducing the risk of MOLT with a weighted benefit-risk ratio for patients with PBC. Monotherapy with DPM, CYP, AZP or MTX received statistical significance in causing AEs where treatment with DPM showed higher probabilities of being at the superior ranking positions in AEs. These estimates are fairly robust and changed little in sensitivity analyses.

Our study has several strengths. Firstly, our network meta-analysis, until more evidences of direct active comparisons are reported, provides a useful and complete picture for propensity of most comprehensive treatments associated with efficacy and safety outcomes among patients with PBC. Network meta-analysis allowed comparison of all available strategies in a single analysis to give a combined total 4182 patients of treatments, rather than separate and disconnected meta-analyses for individual pairs of treatments. Secondly, we were able to provide a formal rank order for all treatment strategies by their capacity to reduce the risk of MOLT or AEs by conducting a network meta-analysis, and this is only attainable by using a Bayesian approach. Finally, in order to reduce concerns on potential inconsistency, we performed inconsistency diagnostic for all triangular and quadrilateral loops. In addition, statistical heterogeneity was moderate, although for some $\mathrm{I}^{2}$ values of comparisons, heterogeneity was high (Table 2). In order to test the robustness of our results due to high heterogeneity values in some comparisons, we performed sensitivity analysis regarding to patients administrated by high (more than 500 $\mathrm{mg} / \mathrm{kg} /$ day) dose of UDCA (BEF plus UDCA excluded), which showed that the results was similar to our main analysis. Furthermore, we analyzed the effects of AEs to obtain a favorable benefit-risk ratio for patients with PBC based on all treatments.

We do also have to acknowledge several limitations in the analysis. Firstly, it may be argued that the inclusion of trial patients with optimum dose of UDCA and trials with high dose may have biased results. However, a sensitivity analysis excluding trials in trials where patients were administrated by high dose of UDCA yielded much 
the same results as the primary analysis. Secondly, the study size assigned to different comparisons was overall small in most included studies in this analysis. However, our study had established the largest PBC treatment sample size for trials performed to date in the world. Thirdly, Factors such as trial heterogeneity, bias and inconsistency can affect the estimates reported in the study [56]. For instance, this analysis was performed on the assumption of consistency where the validity of indirect comparisons was determined by the extent of clinical and methodological trial similarity. However, inconsistency remains a methodological issue of multiple treatment comparisons, as it arises from pooling the data and small number of trials available for the different comparisons resulting in discrepancies between the direct and indirect comparisons, and consequently threatening the validity of the results [56-58]. Furthermore, we are unable to provide comparisons of drug efficacy based on disease duration, MELD, and the presence of cirrhosis due to lack of the above information reported from included trials. Hence, further studies need to be conducted on disease duration, MELD, and the presence of cirrhosis. In the case of our network meta-analysis, the indirect estimates were often very similar to those obtained in the direct comparisons because only single comparisons were available for the majority of the cases. This resulted in a less conventional geometry where our network of trials did not have any closed loops. Finally, our analysis was that not all AE outcomes of interest were reported consistently across trials. Furthermore, there were cases where no events had occurred for the outcome of interest resulting in the requirement to add a continuity correction to the results [58]. In general, missing data resulted in wider credible intervals due to greater uncertainty around the estimates. However, despite these limitations, this network meta-analysis provides the largest scale comparative information on the major clinical outcome profiles of different interventions in current use.

Our study results are consistent with some of previous pairwise meta-analyses, but the network metaanalysis incorporates both direct and indirect comparisons of treatment strategies, including those that have never been compared directly. UDCA appears a safe regimen and may be useful for preventing the progression of $\mathrm{PBC}$, which is the only therapy approved by the U.S. Food and Drug Administration [59]. However, one traditional meta-analysis in 2008 [10] and another published in 2012 [11] of 16 RCTs both reported that, although differing not significantly, they did not demonstrate any benefit of UDCA on mortality and MOLT of patients with PBC. These findings are consistent with our results. In addition, some trials have also concluded that UDCA has no beneficial effect on patient survival, but may be a safe option for patients with PBC. As previously reported in a Canadian Multicenter RCT (reference here), UDCA, when administered to patients with $\mathrm{PBC}$, led to an improvement in clinical outcomes. However, a larger data sample is needed to determine whether UDCA therapy has a beneficial effect on PBC patient survival. Hence, one possible explanation for seemingly inconsistent results, was that the small patient population in those trials which supported UDCA was beneficial to patients.

Although our analysis did not demonstrate that combination therapy of COT with UDCA had a significant risk reduction in MOLT, we found the evidence favoring COT plus UDCA compared with OBS (HR 2.01, 95\%CI 0.5 to 8.84 ), and further network meta-analysis results also revealed similar non-significant relationship. The results of our analysis on efficacy are remarkably similar with several studies. A previous meta-analysis in 2013 [60] was performed of RCTs concluded that the combination therapy of UDCA and COT was more effective in comparison to monotherapy with UDCA for patients with $\mathrm{PBC}$, which we also found in both our direct and indirect comparisons. Similarly, two RCTs [61-62] of the analysis showed that COT plus UDCA appeared to be the best therapeutic option for PBC patients. In addition, COT plus UDCA had the probability of being ranked second with respect to safety outcome. Few AEs were reported, which included osteoporosis, bleeding, aggravated itching, and diarrhea in only two included RCTs [26, 29] associated with COT plus UDCA.

Besides, other single therapies, such as DPM, CYP, AZP or MTX, were also evaluated by several studies. The results of our analysis showed compared with OBS, CYP, DPM or MTX were significantly more likely to cause AEs. Further, no survival benefits can also be found in treatments with CYP, AZP, MTX or MTX. As reported by AASLD in 2009 [59], the clinical guidelines do not recommend any of above treatments. Some headto-head meta-analyses [63-65] all found that treatments with AZP, CYP or MTX did not appear to reduce the risk of MOLT, and led to more AEs for patients with PBC, which are consistent with our results. As is showed in our analysis, treatment with DPM had the highest probabilities of being ranked top in adverse-effects, which included rash, thrombocytopenia, myasthenia, arthralgia, etc [42$43,48,52]$. In addition, two following traditional metaanalyses [66-67] showed that treatment with DPM was associated with little clinical benefits over OBS, and increased the risk of causing the AEs. Therefore, based on our analysis incorporating direct and indirect evidences, there was little evidence favoring the use of these single drugs in clinical efficacy or safety profile.

In conclusion, the study suggests that the superiority of using COT plus UDCA in the treatment of PBC with weighted benefit-risk ratio in MOLT and AEs. For outcome of AEs, UDCA-based therapies, such as UDCA, COT plus UDCA or COC plus UDCA, all showed welltolerated in adverse effects. While single treatments with CYP, DPM or MTX all have achieved statistically significant as compared with OBS, increased risk of AEs 
where DPM was most likely to cause AEs.

\section{MATERIALS AND METHODS}

\section{Search strategy}

We adhered to the PRISMA (Preferred Reporting Items for Systematic reviews and Meta-Analyses) statement for reporting systematic reviews and metaanalyses in healthcare interventions (Supplementary 4) [68]. Four electronic databases (PubMed, Scopus, Embase, and the Cochrane Library) were searched until the end of August 2014 for randomized controlled trials investigating any treatments for patients with $\mathrm{PBC}$, with the key terms "treatments/therapies, primary biliary cirrhosis, randomized clinical trial" without any language or date restrictions. We also searched the additional studies in the reference lists of all identified publications, including relevant meta-analyses and systematic reviews. Two reviewers (Zhu GQ, Huang S) independently assessed the eligibility of all potential abstracts and titles. Any disagreements were resolved through discussion and repeat extraction by a third reviewer (Zheng MH).

\section{Selection criteria}

We included randomized, placebo, or untreated controlled clinical trials comparing the effects of any single or combination of treatments with observation or other classes of active treatments in patients with PBC older than 18 years old. Included studies had to report at least one of two outcomes: MOLT and adverse events (AEs). PBC was diagnosed according to established diagnostic criteria (at least three of the following criteria: alkaline phosphatase and (or gamma glutamyl transpeptidase above the upper limit of normal; antimitochondrial antibodies positive at a titer of 1:40; absence of biliary obstruction by ultrasonography or other radiological tests; or compatible liver biopsy). Other exclusions were trials that comprised a non-randomized design, reviews or pooled-analyses and assessments of other therapies and studies with no usable outcomes data. Duplications were eliminated for the same title, author list or publication date. Eligible studies had to be published as full length articles.

\section{Data extraction}

Two investigators (Zhu GQ, Shi KQ) independently extracted data from each study and enter it into a database. Any discrepancies regarding the extraction of data were resolved by additional investigator (Zheng $\mathrm{MH}$ ). Data were extracted from each study with a predesigned electronic database, including publication data (the first author's name, year of publication, and country of population studied), treatment protocols that were compared and number of patients assigned to each group, the number of events of interest in each group. When relevant information on design or outcomes was unclear, or when doubt existed about duplicate publications, we contacted the original authors for clarification. We choose two clinically meaningful events to estimate efficacy and safety separately of treatments for network metaanalysis: MOLT, which was commonly considered as the most important evaluation, and AEs, including serious events (defined as any untoward medical occurrence that was life threatening, resulted in death, or was persistent or led to significant disability) or non-serious events (that is, any medical occurrence not necessarily having a causal relationship with the treatment). When relevant information on design or outcomes was unclear, or when some needed data was unavailable directly from the study, the original authors were contacted for clarifications and assistance by email.

\section{Study quality}

Two independent reviewers assessed the quality of the methodology by using the Cochrane Risk of Bias Tool, an established tool based on assessing sequence generation for the randomization of subjects, allocation concealment of treatment, blinding, incomplete outcome data, selective outcome reporting and other sources of bias [69]. Trials with high or unclear risk for bias for any one of the first three components were regarded as trials with high risk of bias. Otherwise, they were considered as trials with low risk of bias.

\section{Data analysis}

All data from each eligible study were extracted and entered into a standardized spreadsheet (Microsoft Excel 2007; Microsoft, Redmond, WA). We analyzed two treatment outcomes separately (MOLT, AE). Firstly, traditional pairwise meta-analyses were conducted for studies that directly compared different treatment arms. Then we performed Bayesian network meta-analyses to compare different PBC therapies.

Firstly, we performed traditional pairwise metaanalyses for studies that directly compared different treatment arms with STATA 12.0 (Stata Corporation, College Station, Texas, USA). We calculated, by using the method of DerSimonian and Laird random effects model, of hazards ratios, the pooled estimates of odds ratios and $95 \%$ confidence intervals of direct comparisons between two strategies according to Cochrane Handbook for Systematic Reviews of Interventions Version 5.1.0. Clinical heterogeneity was first assessed through clinical judgment with input from experts in the field. Statistical 
heterogeneity was then assessed by the $P$ values of Egger's and Begg's test from pair-wise meta-analysis, which was higher than 0.05 suggesting heterogeneity. A formal assessment of heterogeneity was then accomplished by referring to the $\mathrm{I}^{2}$ statistic. According to the standard guidelines, $\mathrm{I}^{2}$ values greater than $50 \%$ are considered high heterogeneity levels, between $25-50 \%$ moderate and less than $25 \%$ considered low heterogeneity levels. Once the heterogeneity was suspected, sensitivity analysis was employed [70]. It was conducted based on the important covariate, the dose of UDCA, to investigate the robustness of our main analyses. The sensitivity analysis for dose of UDCA included trials that patients administrated by a dose of $13-15 \mathrm{mg} / \mathrm{kg} /$ day, according to AASLD practice guidelines in 2009 [59].

In addition to the direct comparison meta-analyses, we performed multiple-treatment meta-analysis with a random-effects model within a Bayesian framework using Markov chain Monte Carlo methods in WinBUGS (MRC Bio- statistics Unit, Cambridge, UK). The advantages of using a bayesian analytical approach are that direct probability statements on treatment comparisons can be made and that all evidence for a specific problem can be taken into account as it includes evidence on both indirect and direct comparisons and as such allows estimation of the comparisons between interventions that have not been examined directly in previous trials $[16,18]$. The pooled estimates were obtained using the Markov chains Monte Carlo method. As we have described in our previous published network meta-analysis [2, 26, 30, 39], analyses were based on non-informative priors for relative-effect parameters (flat normal with mean of 0 and precision of 0.001 ) and between-study SD (a flat uniform distribution between 0 and 2). Convergence and lack of autocorrelation were checked and confirmed after a 5000-simulation burn-in phase without any thinning and using 4 chains with different initial values. Then, a burn-in phase of 20 000 iterations was used, followed by 50000 iterations to estimate parameters. This method combined direct and indirect evidence for any given pair of treatments in one joint analysis [71-72].

We compared the pooled HRs from the network meta-analysis with corresponding HRs from pair-wise random-effects meta-analysis of direct comparisons to assess whether there was inconsistency between direct and indirect comparisons. Odds ratios (ORs) were calculated from the number of total patients and the number of patients in each trial for network meta-analysis for AEs. In addition, to estimate inconsistency, we used the node splitting method to calculate the inconsistency of the model, which separated evidence on a particular comparison into direct and indirect evidence [72]. Bayesian $P$ value was also reported and evaluated between the direct and indirect evidence [72].

The treatments were ranked for each outcome in each simulation on the basis of their posterior probabilities. We assessed the probability that each treatment was the most efficacious regimen, the second best, the third best and so on, by calculating the HR for each treatment compared with an arbitrary common group and counting the proportion of iterations of the Markov chain in which each treatment had the highest HR, the second highest, and so on. Even though the differences in effect size among treatments may be small, clinical decisions about the choice of treatments can still be suggested based on the probabilities of treatment ranking $[26,73]$. The outcome of AEs was also reported as odds ratios with corresponding $95 \%$ credible intervals, as well as the probabilities of ranking by treatment. Therefore, the network meta-analysis increased statistical power by incorporating evidence from both direct and indirect comparisons across all treatments.

\section{ACKNOWLEDGMENTS}

Author contributions: Zhu GQ, Huang S, Shi KQ, Chen YP and Zheng MH designed the study. Zhu GQ, Huang S, Huang GQ and Wang JT screened studies and extracted data. Zhu GQ, Huang GQ, Zhou ZR did the statistical analyses. Lin YQ, Wang LR, Wu YM prepared figures. Zhu GQ, Shi KQ, Huang S, Braddock M, Zhou MT and Zheng $\mathrm{MH}$ reviewed the results, interpreted data, and wrote the manuscript. All authors have made an intellectual contribution to the manuscript and approved the submission.

\section{CONFLICTS OF INTEREST}

The authors report no declarations of interest.

\section{FUNDING INFORMATION}

This work was supported by grants from the Scientific Research Foundation of Wenzhou, Zhejiang Province, China (H20090014, Y20090269, , Y20140696), Health Bureau of Zhejiang Province (2010KYB070), Research Foundation of Education Bureau of Zhejiang Province (Y201009942), Fresh Talent Program for Science and Technology Department of Zhejiang Province (2013R413018, 2013R413035 and 2013R413015), Research Funds for Tian Qing Liver Diseases (TQGB20120057) and Project of New Century 551 Talent Nurturing in Wenzhou, Zhejiang Provincial Program for the Cultivation of High-level Innovative Health talents, Ministry of health of China-the major medicine science and technology project in Zhejiang province (No. WKJ2012-2-033), National Natural Science Foundation of China (81370563), Zhejiang Provincial Natural Science Foundation of China (LR14H030001). 


\section{REFERENCES}

1. Hohenester S, Oude-Elferink RP, Beuers U. Primary biliary cirrhosis. Seminars in immunopathology. 2009;31:283-307.

2. Zhu GQ, Shi KQ, Huang S, Huang GQ, Lin YQ, Zhou ZR, Braddock M, Chen YP, Zheng MH. Network metaanalysis of randomized controlled trials: efficacy and safety of UDCA-based therapies in primary biliary cirrhosis. Medicine. 2015;94:e609.

3. Kaplan MM, Cheng S, Price LL, Bonis PA. A randomized controlled trial of colchicine plus ursodiol versus methotrexate plus ursodiol in primary biliary cirrhosis: tenyear results. Hepatology (Baltimore, Md.). 2004;39:915923.

4. Heathcote EJ, Cauch-Dudek K, Walker V, Bailey RJ, Blendis LM, Ghent CN, Michieletti P, Minuk GY, Pappas SC, Scully LJ, et al. The Canadian Multicenter Doubleblind Randomized Controlled Trial of ursodeoxycholic acid in primary biliary cirrhosis. Hepatology (Baltimore, Md.). 1994;19:1149-1156.

5. Lindor KD, Dickson ER, Baldus WP, Jorgensen RA, Ludwig J, Murtaugh PA, Harrison JM, Wiesner RH, Anderson ML, Lange SM, et al. Ursodeoxycholic acid in the treatment of primary biliary cirrhosis. Gastroenterology. 1994;106:1284-1290.

6. Poupon RE, Poupon R, Balkau B. Ursodiol for the longterm treatment of primary biliary cirrhosis. The UDCAPBC Study Group. The New England journal of medicine. 1994;330:1342-1347.

7. Combes B, Carithers RL, Jr., Maddrey WC, Lin D, McDonald MF, Wheeler DE, Eigenbrodt EH, Munoz SJ, Rubin R, Garcia-Tsao G, et al. A randomized, doubleblind, placebo-controlled trial of ursodeoxycholic acid in primary biliary cirrhosis. Hepatology (Baltimore, Md.). 1995;22:759-766.

8. Lindor KD, Therneau TM, Jorgensen RA, Malinchoc M, Dickson ER. Effects of ursodeoxycholic acid on survival in patients with primary biliary cirrhosis. Gastroenterology. 1996;110:1515-1518.

9. Poupon RE, Lindor KD, Cauch-Dudek K, Dickson ER, Poupon R, Heathcote EJ. Combined analysis of randomized controlled trials of ursodeoxycholic acid in primary biliary cirrhosis. Gastroenterology. 1997;113:884-890.

10. Gong Y, Huang ZB, Christensen E, Gluud C. Ursodeoxycholic acid for primary biliary cirrhosis. The Cochrane database of systematic reviews. 2008:CD000551.

11. Rudic JS, Poropat G, Krstic MN, Bjelakovic G, Gluud C. Ursodeoxycholic acid for primary biliary cirrhosis. The Cochrane database of systematic reviews. 2012;12:CD000551.

12. Ikeda T, Tozuka S, Noguchi O, Kobayashi F, Sakamoto $\mathrm{S}$, Marumo F, Sato C. Effects of additional administration of colchicine in ursodeoxycholic acid-treated patients with primary biliary cirrhosis: a prospective randomized study.
Journal of hepatology. 1996;24:88-94.

13. Poupon RE, Huet PM, Poupon R, Bonnand AM, Nhieu JT, Zafrani ES. A randomized trial comparing colchicine and ursodeoxycholic acid combination to ursodeoxycholic acid in primary biliary cirrhosis. UDCA-PBC Study Group. Hepatology (Baltimore, Md.). 1996;24:1098-1103.

14. Dickson ER, Grambsch PM, Fleming TR, Fisher LD, Langworthy A. Prognosis in primary biliary cirrhosis: model for decision making. Hepatology (Baltimore, Md.). 1989;10:1-7.

15. Tanaka A, Harada K, Ebinuma H, Komori A, Yokokawa J, Yoshizawa K, Abe M, Miyake Y, Kikuchi K, Ohira H, Zeniya M, Yamamoto K, Ishibashi H, et al. Primary biliary cirrhosis - Autoimmune hepatitis overlap syndrome: A rationale for corticosteroids use based on a nationwide retrospective study in Japan. Hepatology research : the official journal of the Japan Society of Hepatology. 2011;41:877-886.

16. Ades AE, Sculpher M, Sutton A, Abrams K, Cooper N, Welton N, Lu G. Bayesian methods for evidence synthesis in cost-effectiveness analysis. Pharmacoeconomics. 2006;24:1-19.

17. Song F, Altman DG, Glenny AM, Deeks JJ. Validity of indirect comparison for estimating efficacy of competing interventions: empirical evidence from published metaanalyses. BMJ. 2003;326:472.

18. Sutton A, Ades AE, Cooper N, Abrams K. Use of indirect and mixed treatment comparisons for technology assessment. Pharmacoeconomics. 2008;26:753-767.

19. Lindor KD, Dickson ER, Jorgensen RA, Anderson ML, Wiesner RH, Gores GJ, Lange SM, Rossi SS, Hofmann AF, Baldus WP. The combination of ursodeoxycholic acid and methotrexate for patients with primary biliary cirrhosis: the results of a pilot study. Hepatology (Baltimore, Md.). 1995;22:1158-1162.

20. Vuoristo M, Farkkila M, Karvonen AL, Leino R, Lehtola J, Makinen J, Mattila J, Friman C, Seppala K, Tuominen J, et al. A placebo-controlled trial of primary biliary cirrhosis treatment with colchicine and ursodeoxycholic acid. Gastroenterology. 1995;108:1470-1478.

21. Leuschner U, Fischer H, Hubner K. [Ursodeoxycholic acid in the treatment of primary biliary cirrhosis: results of a controlled study]. Zeitschrift fur Gastroenterologie. Verhandlungsband. 1989;24:133.

22. Oka H, Toda G, Ikeda Y, Hashimoto N, Hasumura Y, Kamimura T, Ohta Y, Tsuji T, Hattori N, Namihisa $\mathrm{T}$, et al. A multi-center double-blind controlled trial of ursodeoxycholic acid for primary biliary cirrhosis. Gastroenterologia Japonica. 1990;25:774-780.

23. Poupon RE, Balkau B, Eschwege E, Poupon R. A multicenter, controlled trial of ursodiol for the treatment of primary biliary cirrhosis. UDCA-PBC Study Group. The New England journal of medicine. 1991;324:1548-1554.

24. Battezzati PM, Podda M, Bianchi FB, Naccarato R, Orlandi 
F, Surrenti C, Pagliaro L, Manenti F. Ursodeoxycholic acid for symptomatic primary biliary cirrhosis. Preliminary analysis of a double-blind multicenter trial. Italian Multicenter Group for the Study of UDCA in PBC. Journal of hepatology. 1993;17:332-338.

25. Hwang SJ, Chan CY, Lee SD, Wu JC, Tsay SH, Lo KJ. Ursodeoxycholic acid in the treatment of primary biliary cirrhosis: a short-term, randomized, double-blind controlled, cross-over study with long-term follow up. Journal of gastroenterology and hepatology. 1993;8:217223.

26. Zhu GQ, Shi KQ, You J, Zou H, Lin YQ, Wang LR, Braddock M, Chen YP, Zheng MH. Systematic review with network meta-analysis: adjuvant therapy for resected biliary tract cancer. Alimentary pharmacology \& therapeutics. 2014;40:759-770.

27. Eriksson LS, Olsson R, Glauman H, Prytz H, Befrits R, Ryden BO, Einarsson K, Lindgren S, Wallerstedt S, Weden M. Ursodeoxycholic acid treatment in patients with primary biliary cirrhosis. A Swedish multicentre, doubleblind, randomized controlled study. Scandinavian journal of gastroenterology. 1997;32:179-186.

28. Gonzalez-Koch A, Brahm J, Antezana C, Smok G, Cumsille MA. The combination of ursodeoxycholic acid and methotrexate for primary biliary cirrhosis is not better than ursodeoxycholic acid alone. Journal of hepatology. 1997;27:143-149.

29. Chazouilleres O, Wendum D, Serfaty L, Montembault S, Rosmorduc O, Poupon R. Primary biliary cirrhosisautoimmune hepatitis overlap syndrome: clinical features and response to therapy. Hepatology (Baltimore, Md.). 1998;28:296-301.

30. Zhu GQ, You J, Shi KQ, He SY, Wang LR, Chen YP, Braddock M, Zheng MH. Systematic review with network meta-analysis: adjuvant chemotherapy for resected colorectal liver metastases. Medicine. 2015;94:e379.

31. Almasio PL, Floreani A, Chiaramonte M, Provenzano G, Battezzati P, Crosignani A, Podda M, Todros L, Rosina F, Saccoccio G, Manenti F, Ballardini G, Bianchi FP, et al. Multicentre randomized placebo-controlled trial of ursodeoxycholic acid with or without colchicine in symptomatic primary biliary cirrhosis. Alimentary pharmacology \& therapeutics. 2000;14:1645-1652.

32. Pares A, Caballeria L, Rodes J, Bruguera M, Rodrigo L, Garcia-Plaza A, Berenguer J, Rodriguez-Martinez D, Mercader J, Velicia R. Long-term effects of ursodeoxycholic acid in primary biliary cirrhosis: results of a double-blind controlled multicentric trial. UDCACooperative Group from the Spanish Association for the Study of the Liver. Journal of hepatology. 2000;32:561-566.

33. Battezzati PM, Zuin M, Crosignani A, Allocca M, Invernizzi P, Selmi C, Villa E, Podda M. Ten-year combination treatment with colchicine and ursodeoxycholic acid for primary biliary cirrhosis: a double-blind, placebocontrolled trial on symptomatic patients. Alimentary pharmacology \& therapeutics. 2001;15:1427-1434.

34. Papatheodoridis GV, Hadziyannis ES, Deutsch M, Hadziyannis SJ. Ursodeoxycholic acid for primary biliary cirrhosis: final results of a 12-year, prospective, randomized, controlled trial. The American journal of gastroenterology. 2002;97:2063-2070.

35. Kanda T, Yokosuka O, Imazeki F, Saisho H. Bezafibrate treatment: a new medical approach for PBC patients? Journal of gastroenterology. 2003;38:573-578.

36. Ozaslan E, Efe C, Akbulut S, Purnak T, Savas B, Erden E, Altiparmak E. Therapy response and outcome of overlap syndromes: autoimmune hepatitis and primary biliary cirrhosis compared to autoimmune hepatitis and autoimmune cholangitis. Hepato-gastroenterology. 2010;57:441-446.

37. Leung J, Bonis PA, Kaplan MM. Colchicine or methotrexate, with ursodiol, are effective after 20 years in a subset of patients with primary biliary cirrhosis. Clinical gastroenterology and hepatology : the official clinical practice journal of the American Gastroenterological Association. 2011;9:776-780.

38. Combes B, Emerson SS, Flye NL, Munoz SJ, Luketic VA, Mayo MJ, McCashland TM, Zetterman RK, Peters MG, Di Bisceglie AM, Benner KG, Kowdley KV, Carithers RL, Jr., et al. Methotrexate (MTX) plus ursodeoxycholic acid (UDCA) in the treatment of primary biliary cirrhosis. Hepatology (Baltimore, Md.). 2005;42:1184-1193.

39. Zhu GQ, Shi KQ, Huang S, Wang LR, Lin YQ, Huang GQ, Chen YP, Braddock M, Zheng MH. Systematic review with network meta-analysis: the comparative effectiveness and safety of interventions in patients with overt hepatic encephalopathy. Alimentary pharmacology \& therapeutics. 2015;41:624-635.

40. Bodenheimer H, Jr., Schaffner F, Pezzullo J. Evaluation of colchicine therapy in primary biliary cirrhosis. Gastroenterology. 1988;95:124-129.

41. Christensen E, Neuberger J, Crowe J, Altman DG, Popper H, Portmann B, Doniach D, Ranek L, Tygstrup N, Williams R. Beneficial effect of azathioprine and prediction of prognosis in primary biliary cirrhosis. Final results of an international trial. Gastroenterology. 1985;89:1084-1091.

42. Dickson ER, Fleming TR, Wiesner RH, Baldus WP, Fleming CR, Ludwig J, McCall JT. Trial of penicillamine in advanced primary biliary cirrhosis. The New England journal of medicine. 1985;312:1011-1015.

43. Epstein O, Jain S, Lee RG, Cook DG, Boss AM, Scheuer PJ, Sherlock S. D-penicillamine treatment improves survival in primary biliary cirrhosis. Lancet. 1981;1:12751277.

44. Heathcote J, Ross A, Sherlock S. A prospective controlled trial of azathioprine in primary biliary cirrhosis. Gastroenterology. 1976;70:656-660.

45. Hendrickse MT, Rigney E, Giaffer MH, Soomro I, Triger DR, Underwood JC, Gleeson D. Low-dose methotrexate is 
ineffective in primary biliary cirrhosis: long-term results of a placebo-controlled trial. Gastroenterology. 1999;117:400407.

46. Kaplan MM, Alling DW, Zimmerman HJ, Wolfe HJ, Sepersky RA, Hirsch GS, Elta GH, Glick KA, Eagen KA. A prospective trial of colchicine for primary biliary cirrhosis. The New England journal of medicine. 1986;315:14481454.

47. Lombard M, Portmann B, Neuberger J, Williams R, Tygstrup N, Ranek L, Ring-Larsen H, Rodes J, Navasa M, Trepo C, et al. Cyclosporin A treatment in primary biliary cirrhosis: results of a long-term placebo controlled trial. Gastroenterology. 1993;104:519-526.

48. Matloff DS, Alpert E, Resnick RH, Kaplan MM. A prospective trial of D-penicillamine in primary biliary cirrhosis. The New England journal of medicine. 1982;306:319-326.

49. Minuk GY, Bohme CE, Burgess E, Hershfield NB, Kelly JK, Shaffer EA, Sutherland LR, Van Rosendaal G. Pilot study of cyclosporin A in patients with symptomatic primary biliary cirrhosis. Gastroenterology. 1988;95:13561363.

50. Mitchison HC, Palmer JM, Bassendine MF, Watson AJ, Record CO, James OF. A controlled trial of prednisolone treatment in primary biliary cirrhosis. Three-year results. Journal of hepatology. 1992;15:336-344.

51. Neuberger J, Christensen E, Portmann B, Caballeria J, Rodes J, Ranek L, Tygstrup N, Williams R. Double blind controlled trial of d-penicillamine in patients with primary biliary cirrhosis. Gut. 1985;26:114-119.

52. Taal BG, Schalm SW, Ten Kate FW, Van Berge Henegouwen GP, Brandt KH. Low therapeutic value of D-penicillamine in a short-term prospective trial in primary biliary cirrhosis. Liver. 1983;3:345-352.

53. Warnes TW, Smith A, Lee FI, Haboubi NY, Johnson PJ, Hunt L. A controlled trial of colchicine in primary biliary cirrhosis. Trial design and preliminary report. Journal of hepatology. 1987;5:1-7.

54. Wiesner RH, Ludwig J, Lindor KD, Jorgensen RA, Baldus WP, Homburger HA, Dickson ER. A controlled trial of cyclosporine in the treatment of primary biliary cirrhosis. The New England journal of medicine. 1990;322:14191424.

55. Zifroni A, Schaffner F. Long-term follow-up of patients with primary biliary cirrhosis on colchicine therapy. Hepatology (Baltimore, Md.). 1991;14:990-993.

56. Cooper NJ, Sutton AJ, Morris D, Ades AE, Welton NJ. Addressing between-study heterogeneity and inconsistency in mixed treatment comparisons: Application to stroke prevention treatments in individuals with non-rheumatic atrial fibrillation. Statistics in medicine. 2009;28:18611881.

57. Caldwell DM, Welton NJ, Ades AE. Mixed treatment comparison analysis provides internally coherent treatment effect estimates based on overviews of reviews and can reveal inconsistency. Journal of clinical epidemiology. 2010;63:875-882.

58. Friedrich JO, Adhikari NK, Beyene J. Inclusion of zero total event trials in meta-analyses maintains analytic consistency and incorporates all available data. BMC medical research methodology. 2007;7:5.

59. Lindor KD, Gershwin ME, Poupon R, Kaplan M, Bergasa NV, Heathcote EJ, American Association for Study of Liver D. Primary biliary cirrhosis. Hepatology (Baltimore, Md.). 2009;50:291-308.

60. Zhang Y, Lu J, Dai W, Wang F, Shen M, Yang J, Zhu $\mathrm{R}$, Zhang H, Chen K, Cheng P, He L, Wang C, Xu L, et al. Combination therapy of ursodeoxycholic Acid and corticosteroids for primary biliary cirrhosis with features of autoimmune hepatitis: a meta-analysis. Gastroenterology research and practice. 2013;2013:490731.

61. Chazouilleres O, Wendum D, Serfaty L, Rosmorduc O, Poupon R. Long term outcome and response to therapy of primary biliary cirrhosis-autoimmune hepatitis overlap syndrome. Journal of hepatology. 2006;44:400-406.

62. Heurgue A, Vitry F, Diebold MD, Yaziji N, BernardChabert B, Pennaforte JL, Picot R, Louvet H, Fremond L, Geoffroy P, Schmit JL, Cadiot G, Thiefin G. Overlap syndrome of primary biliary cirrhosis and autoimmune hepatitis: a retrospective study of 115 cases of autoimmune liver disease. Gastroenterologie clinique et biologique. 2007;31:17-25.

63. Giljaca V, Poropat G, Stimac D, Gluud C. Methotrexate for primary biliary cirrhosis. The Cochrane database of systematic reviews. 2010:CD004385.

64. Gong Y, Christensen E, Gluud C. Azathioprine for primary biliary cirrhosis. The Cochrane database of systematic reviews. 2007:CD006000.

65. Gong Y, Christensen E, Gluud C. Cyclosporin A for primary biliary cirrhosis. The Cochrane database of systematic reviews. 2007:CD005526.

66. Gong Y, Frederiksen SL, Gluud C. D-penicillamine for primary biliary cirrhosis. The Cochrane database of systematic reviews. 2004:CD004789.

67. Gong Y, Klingenberg SL, Gluud C. Systematic review and meta-analysis: D-Penicillamine vs. placebo/no intervention in patients with primary biliary cirrhosis-Cochrane Hepato-Biliary Group. Alimentary pharmacology \& therapeutics. 2006;24:1535-1544.

68. Moher D, Liberati A, Tetzlaff J, Altman DG. Preferred reporting items for systematic reviews and meta-analyses: the PRISMA statement. International journal of surgery (London, England). 2010;8:336-341.

69. Higgins JP, Altman DG, Gotzsche PC, Juni P, Moher D, Oxman AD, Savovic J, Schulz KF, Weeks L, Sterne JA. The Cochrane Collaboration's tool for assessing risk of bias in randomised trials. BMJ. 2011;343:d5928.

70. Bowden J, Tierney JF, Copas AJ, Burdett S. Quantifying, 
displaying and accounting for heterogeneity in the metaanalysis of RCTs using standard and generalised Q statistics. BMC Med Res Methodol. 2011;11:41.

71. Jansen JP, Fleurence R, Devine B, Itzler R, Barrett A, Hawkins N, Lee K, Boersma C, Annemans L, Cappelleri JC. Interpreting indirect treatment comparisons and network meta-analysis for health-care decision making: report of the ISPOR Task Force on Indirect Treatment Comparisons Good Research Practices: part 1. Value Health. 2011;14:417-428.

72. Lumley T. Network meta-analysis for indirect treatment comparisons. Statistics in medicine. 2002;21:2313-2324.

73. Cipriani A, Furukawa TA, Salanti G, Geddes JR, Higgins JP, Churchill R, Watanabe N, Nakagawa A, Omori IM, McGuire H, Tansella M, Barbui C. Comparative efficacy and acceptability of 12 new-generation antidepressants: a multiple-treatments meta-analysis. Lancet. 2009;373:746758. 